Check for updates

Health Intervention and Technology Assessment Program (HITAP), Department of Health, Muang, Nonthaburi 11000, Thailand

2 Saw Swee Hock School of Public Health, National University of Singapore, Singapore

3 HealthServe, Singapore

Correspondence to: S Dabak saudamini.d@hitap.net

Cite this as: BMJ 2021;373:n1608 http://dx.doi.org/10.1136/bmj.n1608 Published: 25 June 2021

\section{Vaccinating undocumented migrants against covid-19}

\author{
An urgent international endeavour
}

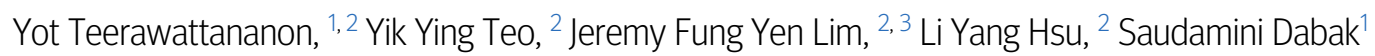

The world is starting to glimpse a possible end to the covid-19 pandemic, thanks to the international rollout of vaccines against SARS-CoV-2. But as these vaccines are delivered around the globe, some groups are being left out, putting everyone in harm's way. Undocumented migrants, including migrant workers, refugees, and other displaced people, are one such group.

Many undocumented migrant workers are young and outside the high risk groups defined by the World Health Organization's "values framework" for the allocation and prioritisation of vaccines. ${ }^{1}$ But these populations are particularly vulnerable to the virus: many live in densely packed quarters and rely on low income jobs where it is impossible to socially distance. They may have limited access to personal protective equipment and healthcare and have higher rates of conditions such as obesity and diabetes that contribute to covid-19 complications. ${ }^{23}$ Vulnerability among migrant groups is a complex issue, involving individual, household, community, and structural factors, all of which are exacerbated by the pandemic. ${ }^{4}$

Many low and middle income countries are struggling to secure enough vaccines for their populations, ${ }^{5}$ and prioritising migrant groups-regardless of their status-will be challenging against a backdrop of limited resources.

The best way to ensure that undocumented migrants are vaccinated, particularly in struggling middle income countries, is for the international community to lend its support. The Covax facility, for example, should extend its offerings to these populations. Other organisations should also contribute, including national governments and UN groups such as the International Labour Organisation (ILO) and the International Organisation for Migration (IOM). This is not a challenge that any one country or organisation should face alone.

\section{Collective effort}

Covax emerged to help low income countries secure vaccines for their high risk populations. ${ }^{6}$ But this protection does not, as yet, extend to citizens of low income countries who are living undocumented elsewhere. More than 1.8 million (or 4 million by some estimates) people from Myanmar are living in Thailand, for example, and will not benefit from Myanmar's access to Covax vaccines. ${ }^{7} 8$

Some progress has been made over the past year. In November, the IOM signed a memorandum of understanding with Gavi, the global vaccine alliance, to help reach migrant, refugee, and displaced populations. ${ }^{9}$ And a recent statement by the UN Network on Migration called on governments to provide vaccinations for all migrants, regardless of their status. ${ }^{10}$ These are excellent moves, but the implementation details remain unclear.

Barriers to access remain because many undocumented migrants fear punitive action if they step forward for vaccination. Vaccination programmes targeted through trusted community health workers or non-profit organisations may be one way to encourage uptake. Alternatively, governments should consider setting up vaccination centres that do not require formal identification or registration before vaccination. Coordination among government agencies from health and immigration sectors will be needed to ensure vaccination programmes are not used by immigration authorities for tracking or enforcement. A moratorium on prosecuting undocumented migrants may also encourage vaccination uptake. Transparent communication of the prioritisation process is important to ensure public acceptance of this approach, as was done in Singapore, where migrant workers were prioritised for vaccination alongside older adults and essential health workers. ${ }^{11}$

The pandemic may provide an opportunity for some countries to extend registration programmes for migrants, offering an official pathway to regularisation of their status and potentially extending healthcare-not just covid-19 vaccines-to a larger population.

Thailand already allows undocumented migrants to register for healthcare without threat of penalty, although uptake has been low. ${ }^{12}$ The pandemic may also encourage companies to ensure that all employees are registered and offered vaccination to avoid outbreaks that could jeopardise productivity. ${ }^{13}$

\section{Measuring success}

Countries must be accountable for vaccinating those living within their borders, including both documented and undocumented migrants. Rates of vaccination among migrant groups could be used to measure the success of a country's vaccination programme, for example. The ILO alongside others, could be a leading global voice in the protection of these workers' rights. Countries should also consider bilateral agreements to help increase vaccination rates when one country is a dominant source of migrant workers for the other.

This is a challenging task. However, all nations must work together to protect the vulnerable and extend healthcare to everyone, for "no one is safe, until everyone is safe."

Competing interests: We have read and understood BMJ policy on declaration of interests and have no interests to declare. 
Provenance and peer review: Not commissioned; externally peer reviewed.

This editorial was developed after round table discussions, a collaboration between the Saw Swee Hock School of Public Health, National University of Singapore and the Health Intervention and

Technology Assessment Program (HITAP), Ministry of Public Health, Thailand. We thank attendees for their contribution: Rakesh Aggarwal, Ronaldo R Quintana, Awang Bulgiba Bin Awang, Hannah Clapham, Alex Cook, Raymond Hutubessy, Soewarta Kosen, Piyamitr Sritara, Benjamin Ong, Clarence Tam, and Pham Quang Thai. We also thank Nicola Jones for editorial support.

1 WHO. WHO SAGE values framework for the allocation and prioritization of COVID-19 vaccination. 2020. https://apps.who.int/iris/handle/10665/334299.

2 Sattar N, Gill JM. Type 2 diabetes in migrant south Asians: mechanisms, mitigation, and management. Lancet Diabetes Endocrinol 2015;3:1004-16. doi: 10.1016/S2213-8587(15)00326-5 pmid: 26489808

3 Centres for Disease Prevention and Control. Health equity considerations and racial and ethnic minority groups. 2021. https://www.cdc.gov/coronavirus/2019-ncov/community/health-equity/race-ethnicity.html.

4 International Organisation for Migration. Handbook on protection and assistance for migrants vulnerable to violence, exploitation and abuse. IOM, 2019.

5 The covid resilience ranking. US, Europe rise in best places to be in covid; Asia suffers. Bloomberg 2021 May 25. https://www.bloomberg.com/graphics/covid-resilience-ranking/.

6 WHO. Covax publishes first round of allocations. 2021 https://www.who.int/news/item/02-032021-covax-publishes-first-round-of-allocations.

7 Chongkittavorn K. Migrant workers need better welfare. Bangkok Post 2020 Dec 20.

https://www.bangkokpost.com/opinion/opinion/2039215/migrant-workers-need-better-welfare.

8 Chalamwong Y. How to protect over 2 million migrant workers in Thailand from Covid-19. Thailand Development Research Institute, 2020. https:/tdri.or.th/en/2020/05/how-to-protect-migrantworkers-in-thailand-from-covid-19/.

9 Gavi the Vaccine Alliance. Gavi and IOM join forces to improve immunisation coverage for migrants. 2020. https://www.gavi.org/news/media-room/gavi-and-iom-join-forces-improve-immunisationcoverage-migrants.

10 United Nations Network on Migration. Striving for equitable access to covid-19 vaccines to leave no migrant behind. 2021. https://migrationnetwork.un.org/striving-equitable-access-covid-19vaccines-leave-no-migrant-behind.

11 Singapore Ministry of Health. Covid-19 vaccination brought forward for all seniors; extended to essential services personnel and higher risk groups. 2021. https://www.moh.gov.sg/news-highlights/details/covid-19-vaccination-brought-forward-for-all-seniors-extended-to-essential-servicespersonnel-and-higher-risk-groups.

12 Legido-Quigley H, Pocock N, Tan ST, etal. Healthcare is not universal if undocumented migrants are excluded. BMJ 2019;366:14160. doi: 10.1136/bmj.14160 pmid: 31527060

13 Coronavirus halts shrimp exports to China. VN Express 2020 Feb 12. https://e.vnexpress.net/news/business/industries/coronavirus-halts-shrimp-exports-to-china-4053453.html.

This article is made freely available for use in accordance with BMJ's website terms and conditions for the duration of the covid-19 pandemic or until otherwise determined by BMJ. You may use, download and print the article for any lawful, non-commercial purpose (including text and data mining) provided that all copyright notices and trade marks are retained. 